\title{
Analisis Faktor Otentik Kesulitan Belajar Program Linier Berbasis Problem- based learning
}

\author{
Aris Tamarudin ${ }^{1 \bowtie}$ dan Irfai Fathurohman ${ }^{2}$ \\ ${ }^{1}$ SMAN 1 Bae Kudus \\ ${ }^{2}$ Program Studi Pendidikan Bahasa dan Sastra Indonesia, Universitas Muria Kudus
}

\begin{abstract}
Info Artikel Abstract
Sejarah Artikel:

Diterima 10 Mei 2020

Direvisi 9 Mei 2020

Disetujui 15 Mei 2020

Keywords: Factors,

Authentic, Learning

Difficulties, Linear

Program, PBL

Paper type:

Research paper

The purpose of this study is twofold, first, to find out the authentic factor of learning difficulties in linear programming based on problem-based learning. Second, knowing the effectiveness of authentic assessment and problem-based learning in overcoming learning difficulties. The method in this research descriptive qualitative method. The subjects of this study were 251st grade students of SMAN 1 Bae Kudus Regency. Analysis of learning difficulties is done by interviews and measurement techniques. The research instrument uses objective tests and essays. The results of this study first, found authentic factors of linear program learning difficulties experienced by students in completing competency test questions. Second, through the use of authentic assessment and problem-based learning, each student's understanding can be clearly identified, so that action can be taken to improve and improve the quality of learning. Through learning that emphasizes the ability of each individual student to be authentically known, the skills of each individual are able to be optimal in accordance with their interests and ways of solving each problem in mathematics learning.
\end{abstract}

\begin{abstract}
Abstrak
Tujuan penelitian ini ada dua, yaitu pertama, mengetahui faktor otentik kesulitan belajar program linier berbasis problem-based learning. Kedua, mengetahui efektivitas penilaian otentik dan problem-based learning dalam mengatasi kesulitan belajar. Metode yang digunakan dalam penelitian ini menggunakan metode kualitatif deskriptif. Subjek penelitian ini adalah siswa kelas XI SMAN 1 Bae Kabupaten Kudus berjumlah 251siswa. Analisis kesulitan belajar dilakukan dengan wawancara dan teknik pengukuran. Instrumen penelitian menggunakan tes objektif dan esai. Hasil penelitian ini pertama, ditemukan faktor-faktor otentik kesulitan belajar program linier yang dialami siswa dalam menyelesaikan soal uji kompetensi. Kedua, melalui penggunaan penilaian otentik dan problem-based learning, maka pemahaman tiap siswa secara nyata dapat teridentifikasi dengan baik, sehingga dapat dilakukan tindakan untuk perbaikan dan peningkatan kualitas pembelajaran. Melalui pembelajaran yang mengedepankan kemampuan tiap individu siswa untuk diketahui kemampuannya secara otentik maka keterampilan tiap individu mampu optimal sesuai dengan minat dan cara dirinya menyelesaikan tiap persoalan dalam pembelajaran matematika.
\end{abstract}

\begin{tabular}{lc}
\hline Alamat korespondensi: & p-ISSN 2615-4196 \\
Program Studi Pendidikan Matematika & e-ISSN 2615-4072 \\
Fakultas Keguruan dan Ilmu Pendidikan Universitas Muria Kudus & \\
Kampus UMK Gondangmanis, Bae Kudus Gd. L. 1t I PO. BOX 53 Kudus & \\
Tlp (0291) 438229 ex.147 Fax. (0291) 437198 & \\
E-mail: aristamarudinsabaku@gmail.com &
\end{tabular}




\section{PENDAHULUAN}

Pembelajaran dikatakan berhasil apabila dalam prosesnya sudah dipersiapkan sejak awal, seperti sudah tersusunnya silabus, RPP, materi, pemanfaatan model, media, dan metode yang digunakan dalam pembelajaran. Adanya perangkat pembelajaran yang sudah memadai merupakan langkah awal dalam menuju proses pembelajaran yang ideal. Persiapan matang yang dilakukan guru dalam pembelajaran tentunya selalu mengalami hambatan ketika di kelas, salahsatunya yakni jika siswa mengalami kesulitan dalam belajar. Kesulitan belajar muncul salahsatunya karena siswa kurang memahami materi, tidak konsentrasi, pengaruh dari faktor eksternal yang ada di kelas, hingga siswa kurang tertarik pada materi pembelajaran yang diajarkan. Berbagai hal yang menggangu pemahaman siswa dalam belajar tentunya menjadi penghambat dalam kelancaran pembelajaran dan hal seperti ini menjadi tugas guru untuk dapat mengatasinya. Hajaroh dan Adawiyah (2018:131) menyatakan bahwa dalam proses pembelajaran, guru berperan sebagai "aktor" dan "instruktur" yang mengatur sepenuhnya kehidupan kelas, saat ini guru diposisikan sebagai "fasilitator" dan "motivator" yang dapat mengaktifkan dan menggairahkan peserta didik berkiprah dalam kehidupan kelas.

Cahyono (2019:2) menjelaskan bahwa pendidikan ialah suatu kebutuhan bagi siapapun dan sampai kapanpun. Pendidikan membuat bangsa menjadi kuat dan masyarakat cendekia. Pemerintah harus menyiapkan generasi penerus bangsa yang berkualitas. Dalam rangka menciptakan pendidikan yang berkualitas dan selaras dengan globalisasi yang semakin berkembang, perlu adanya pendampinga dan kontrol terhadap jalannya pendidikan pada setiap satuan pendidikan. Heyneman \& Lee, (dalam Kusuma dan Hamidah, 2019:65) menyebutkan bahwa tingkat pendidikan seseorang memberi pengaruh terhadap kemungkinan seseorang tersebut menjadi pengangguran dan terjebak dalam kemiskinan.

Permasalahan setiap siswa dengan siswa yang lain dalam memahami kesulitan belajar tentunya berbeda-beda. Tingkat kesulitan yang berbeda antar siswa tidak dapat diatasi dengan tindakan yang sama, namun diperlukan penilaian otentik yang dapat mendeskipsikan dengan jelas kondisi siswa selama proses pembelajaran. Penilaian otentik dapat menggambarkan mengenai kesulitan, hambatan, dan kemajuan siswa dalam pembelajaran. Astriyandi, Chotimah, dan Faisal (2016:189) menjelaskan bahwa penilaian autentik menuntut peserta didik untuk mendemonstrasikan pengetahuan, keterampilan, dan peserta didik harus mampu menghasilkan jawaban atau produk yang dilatarbelakangi oleh pengetahuan teoretis. Dengan demikian, peserta didik akan merasa proses pembelajaran yang dialaminya menjadi lebih bermakna. Mueller (dalam Lismayanti, 2017) menyatakan bahwa kriteria dalam penilaian otentik digunakan untuk mengevaluasi seberapa baik peserta didik menyelesaikan tugas dan seberapa baik mereka telah memenuhi standar. Saodah (2017:20) menjelaskan bahwa penilaian harus dilakukan secara otentik terhadap proses dan hasil belajar. Penilaian sebagai kegiatan evaluasi terhadap program pembelajaran akan menentukan ketercapaian program.

Alawiyah, Muldayanti, dan Setiadi (2016:10) mengatakan bahwa kesulitan belajar apabila tidak segera diatasi akan terus-menerus mengganggu siswa dalam menerima pengetahuanpengetahuan baru. Apabila kesulitan belajar tidak diperhatikan oleh guru, maka berakibat semakin bertambahnya materi yang tidak mampu dipahami secara tuntas. Hal ini, dapat mengakibatkan kekurangmampuan siswa dalam menjawab soalsoal yang diberikan dan akhirnya berdampak pada rendahnya hasil belajar siswa.Oleh karena itu, dibutuhkan berbagai usaha untuk mengatasi masalah tersebut. Kesulitan belajar yang terjadi pada siswa harus dianalisis agar tujuan dari pembelajaran dapat terpenuhi. Badjeber Mailili (2019:7) mengemukakan bahwa siswa yang memiliki pengetahuan konseptual yang baik akan paham bahwa objek dalam matematika saling berkaitan.

Mata pelajaran di SMA yang dianggap sulit dan kurang diminati oleh siswa yakni mata pelajaran matematika. Berdasarkan hasil observasi pada hari Jumat, 6 September 2019 di kelas XI SMAN 1 Bae Kabupaten Kudus diperoleh informasi bahwa siswa memerlukan pengulangan secara terus menerus agar nantinya paham dan mampu mengerjakan soal dengan jawaban yang 
tepat. Matematika membutuhkan konsentrasi dan daya ingat yang tinggi sehingga setiap siswa diupayakan untuk selalu berlatih dan belajar untuk mengerjakan soal. Pelatihan selama ini, dilakukan oleh guru kepada siswa selama proses pembelajaran dan dilatih dengan menggunakan tugas terstruktur seperti tugas melalui media online dan ofline sebagai bentuk pelatihan yang mendukung daya logika siswa. Nurafni dan Pujiastuti (2019:28) mengungkapkan bahwa seseorang yang memahami kaitan antar konsep matematika dengan baik, maka ia tidak hanya hapal atau mengingat konsep dalam jangka pendek namun penguasaan konsepnya lebih tahan lama dan ia mampu menerapkan konsep pada situasi lain.

Berdasarkan hasil uji kompetensi pada hari Jumat, 13 September 2019 tentang materi program linier yang telah dilakukan pada kelas XI SMAN 1 Bae Kabupaten Kudus diperoleh data bahwa siswa masih mengalami kendala dalam mengerjakan soal materi program linier. Problematika ini didasari karena beberapa tipe soal tidak dapat dikerjakan dengan benar oleh siswa. Berdasarkan permasalahan tersebut maka judul penelitian ini yakni “Analisis Faktor Otentik Kesulitan Belajar Program Linier Berbasis Problem-Based Learning". Tujuan penelitian ini ada dua yaitu pertama, mengetahui faktor otentik kesulitan belajar program linier berbasis problem-based learning. Kedua, mengetahui efektivitas penilaian otentik dan problem-based learning dalam mengatasi kesulitan belajar.

\section{METODE PENELITIAN}

Penelitian ini menggunakan metode kualitatif deskriptif. Subjek penelitian ini adalah siswa kelas XI SMAN 1 Bae Kabupaten Kudus. Data diperoleh dari hasil tes uji kompetensi. Sumber data diperoleh dari wawancara guru matematika di SMAN 1 Bae Kabupaten Kudus. Teknik pengumpulan data menggunakan observasi, wawancara, dan dokumentasi. Analisis data menggunakan reduksi data, penyajian data, dan penarikan kesimpulan untuk melengkapi hasil wawancara dan teknik pengukuran.

\section{HASIL DAN PEMBAHASAN}

Hasil dan pembahasan dalam penelitian ini terbagi menjadi dua, yaitu pertama, mengetahui faktor otentik kesulitan belajar program linier berbasis problem-based learning. Kedua, mengetahui efektivitas penilaian otentik dan problem-based learning dalam mengatasi kesulitan belajar. Berikut ini dipaparkan hasil dan pembahasan penelitian yang telah dilakukan oleh peneliti:

\section{A. Faktor Otentik Kesulitan Belajar Program Linier Berbasis Problem-Based Learning}

Berdasarkan hasil penelitian tentang kesulitan belajar program linier melalui uji kompetensi untuk mengetahui faktor otentik kesulitan belajar, maka diperoleh data hasil nilai siswa seperti pada Tabel 1. Tentang Prosentase Ketuntasan Nilai Uji Kompetensi Program Linier.

Tabel 1. Tentang Prosentase Ketuntasan Nilai Uji Kompetensi Program Linier.

\begin{tabular}{llll}
\hline No. & Rentang Nilai & $\begin{array}{c}\text { Jumlah } \\
\text { Siswa }\end{array}$ & Prosentase \\
\hline 1. & $85-100$ & 53 & $21.12 \%$ \\
2. & $70-85$ & 115 & $45.82 \%$ \\
3. & $55-70$ & 32 & $12.75 \%$ \\
4. & $40-55$ & 23 & $9.16 \%$ \\
5. & $25-40$ & 18 & $7.17 \%$ \\
6. & $0-25$ & 10 & $3.98 \%$ \\
\hline
\end{tabular}

Berdasarkan data pada Tabel 1. maka diperoleh informasi bahwa beberapa siswa masih memerlukan refleksi dan evaluasi lebih mendalam untuk memahami penyelesaian soal pada materi program linier. Thursan Hakim (dalam Rahmah, 2013:90-91) menjelaskan bahwa langkah-langkah mengatasi kesulitan belajar adalah sebagai berikut: 1). Lakukan diagnosis kesulitan belajar untuk menentukan apakah seseorang siswa mengalami kesulitan belajar atau tidak. 2). Pahamilah kembali faktor-faktor apa saja yang dapat mempengaruhi keberhasilan belajar. 3). Setelah sumber latar belakang dan penyebab kesulitan belajar siswa tersebut dapat diketahui dengan tepat. 4). Sesuai dengan jenis kesulitan belajar yang dialami siswa dan jenis bimbingan yang perlu diberikan kepadanya, tentukan pula kepada siapa kiranya yang ia perlu berkonsultasi. 5). Lakukan evaluasi untuk mengetahui sejauh mana kesulitan belajar siswa tersebut hendaknya dilakukan secara kontinu sampai kesulitan belajar siswa tersebut telah dapat diatasi. 6). Apabila evaluasi yang 
dilakukan menunjukan bahwa kesulitan belajar siswa tersebut telah dapat diatasi, tindakan selanjutnya adalah melakukan perbaikan untuk meningkatkan prestasi belajarnya, sesuai dengan potensi yang ada pada dirinya.

Berdasarkan teori yang dikemukakan oleh Thursan Hakim (dalam Rahmah, 2013:90-91) maka penelitian ini mengadopsi langkah-langkah tersebut sesuai kebutuhan penelitian.

\section{1) Diagnosis Kesulitan Belajar}

Kesulitan belajar yang dialami siswa dalam pembelajaran materi program linier dapat diketahui dari hasil belajar yang diujikan melalui uji kompetensi yang telah dilaksanakan dengan hasil belajar yang berbeda-beda. Perbedaan ini dipengaruhi oleh tingkat pemahaman siswa tentang materi yang dipelajarinya. Berdasarkan hasil diagnosis yang telah dilakukan diperoleh data bahwa beberapa siswa tidak dapat mengerjakan soal program linier dikarenakan masih sulit untuk memahami soal cerita dan membuat dalam bentuk model matematika. Hal ini berdampak pada kesulitan menentukan titik potong dari sistem persamaan linier dua variabel. Gambar 1 berikut adalah data 1 hasil uji kompetensi program linear.

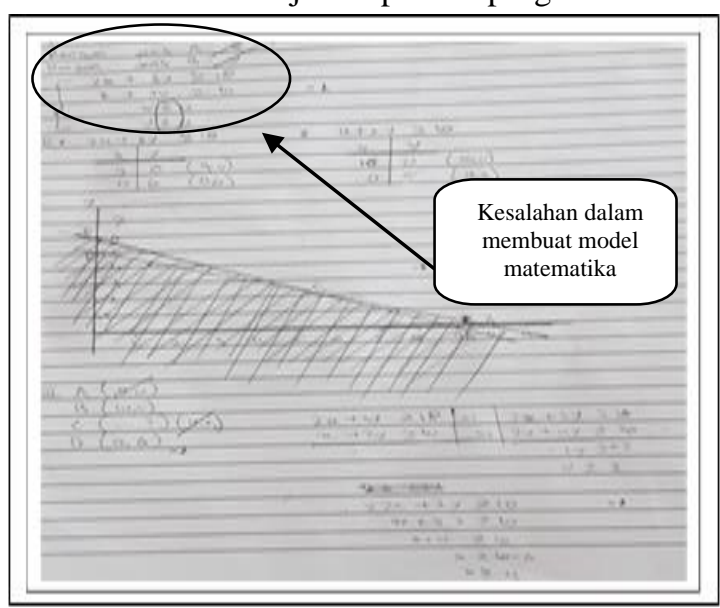

\section{Gambar 1 Data 1 Hasil Uji Kompetensi Program Linier}

Berdasarkan Gambar 1 diketahui bahwa siswa masih perlu memahami soal cerita terkait program linier, hal ini teridentifikasi dari kesalahan siswa dalam mengubah soal ke dalam bentuk model matematika. Kesulitan belajar ini berlanjut ke sistem koordinat kartesius, hal itu terlihat dari kesalahan dalam membuat skala pada sistem koordinat kartesius. Kesulitan belajar yang lain yakni, siswa masih belum tepat menentukan daerah penyelesaian yang berakibat siswa belum benar menentukan titik optimum serta kesulitan menentukan nilai optimum. Gambar 2 berikut adalah data 2 hasil uji kompetensi program linear.

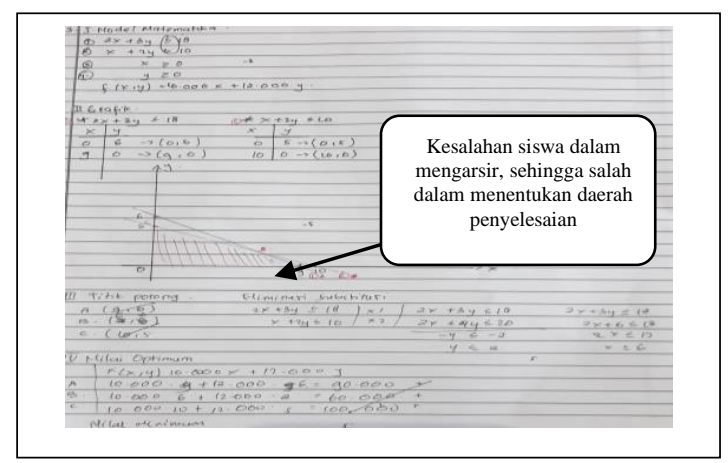

\section{Gambar 2 Data 2 Hasil Uji Kompetensi Program Linear}

Berdasarkan Gambar 2 diperoleh informasi bahwa siswa sudah mengalami perkembangan dengan memahami konsep program linier, hal ini terlihat dari penyelesaian soal yang sudah menerapkan langkah-langkah dengan benar untuk menyelesaikan soal cerita, walaupun masih kurang tepat jawabannya. Kesulitan belajar yang lain yakni siswa belum tepat menentukan daerah penyelesaian yang berakibat siswa belum tepat menentukan titik optimum serta kesulitan menentukan nilai optimum.

\section{2) Faktor-faktor Mempengaruhi Keberhasilan Belajar}

Pengaruh tingkat keberhasilan belajar siswa dipengaruhi oleh faktor dari siswa, guru serta faktor lingkungan belajar. faktor siswa itu diantaranya faktor dari internal siswa itu sendiri, diantaranya motivasi belajar siswa, sedangkan faktor guru juga mempengaruhi keberhasilan belajar siswa, pemilihan model pembelajaran yang dilakukan oleh guru harus tepat dan disesuaikan dengan materi pembelajaran serta sesuai kondisi lingkungan sekitar siswa. 


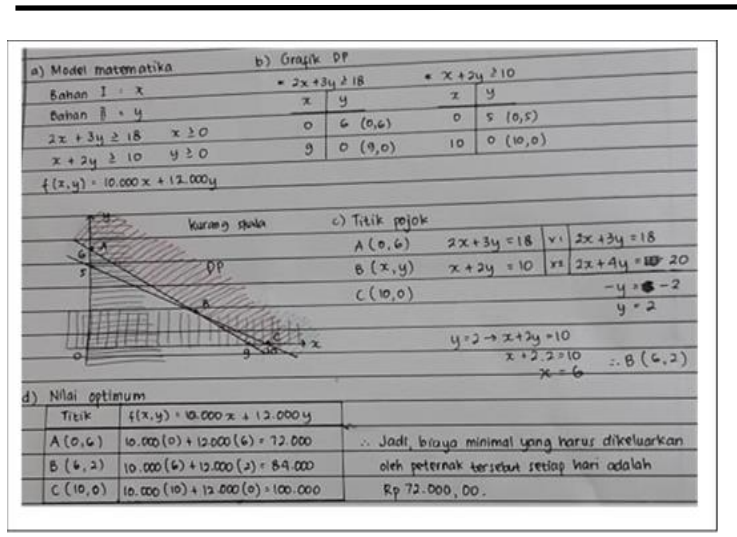

Gambar 3 Data 3 Hasil Uji Kompetensi Program Linier

Gambar 3 menunjukkan suatu faktor yang dipahami siswa dengan baik yakni mampu menyelesaikan soal terkait konsep program linier. Siswa sudah memahami konsep program linier dibuktikan dengan penerapan langkah-langkah yang terstruktur dan benar, proses yang diungkapkan siswa sudah melalui penterjemahaman soal dan membuatnya kedalam model matematika sampai dengan menentukan nilai optimum.

\section{3) Sumber Latar Belakang dan Penyebab Kesulitan Belajar Siswa}

Kesulitan belajar program linear disebabkan karena siswa memiliki kemampuan awal yang masih rendah, siswa juga belum maksimal dalam mengerjakan soal-soal cerita yang beraneka ragam. Masih rendahnya kemampuan dalam memahami bacaan soal cerita berdampak pada kesulitan dalam membuat model matematikanya. Langkah awal mengerjakan program linear siswa harus mampu mengubah soal menjadi model matematika yang berupa sistem pertidaksamaan linear dua variabel. Ada sebagian siswa yang masih kesulitan dalam mencari titik koordinat dari persamaan linear dua variabel, kesulitan itu menyebabkan siswa kesulitan dalam mengambarkan grafiknya, ketika siswa belum mampu mengambar grafiknya maka siswa akan malakukan kesalahan dalam menentukan nilai optimum.

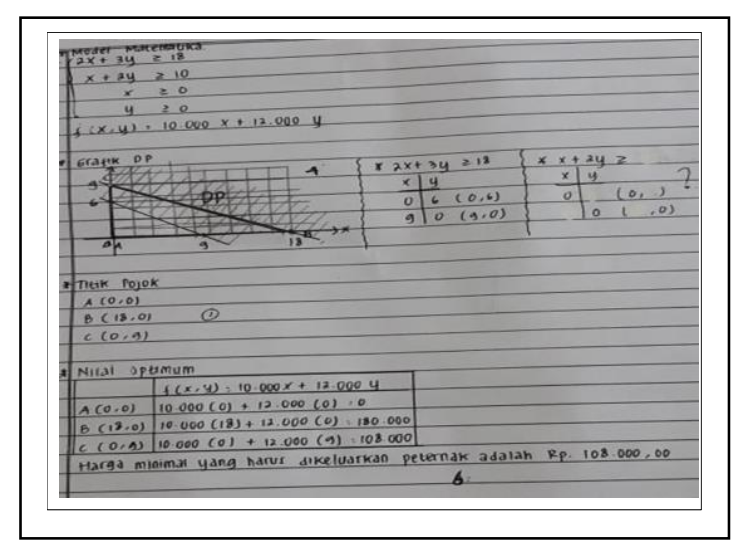

\section{Gambar 4 Data 4 Hasil Uji Kompetensi Program Linier}

Gambar 4 menjelaskan bahwa siswa sudah memahami soal cerita terkait program linier, hal ini terlihat dari siswa yang sudah mampu mengubah soal kedalam bentuk model matematika sudah benar. Namun, siswa mengalami kesulitan dalam membuat titik koordinat dari sistem persamaan linier, sehingga siswa melakukan kesalahan dalam membuat sistem koordinat kartesius, dan membuat kesalahan dalam membuat skla pada sistem koordinat kartesius. Berdasarkan bimbingan secara bertahap, maka perkembangan siswa dapat lebih baik dibuktikan dengan penerapan langkah-langkah yang sudah ada kemajuan.

\section{4) Jenis Kesulitan Belajar yang Dialami Siswa dan Jenis Bimbingan \\ Proses identifikasi terhadap kesulitan} belajar program linier dilakukan melalui empat tahap, yang pertama penggunaan konsep, tindakan, menggali informasi, dan refleksi hasil belajar. Pertama, berdasarkan hasil uji kompetensi diperoleh informasi bahwa siswa kesulitan dalam mendeskripsikan jawaban dikarenakan konsep tentang teori program linier masih belum dipahami dengan baik. Kedua, tindakan yang dilakukan guru yakni melakukan modifikasi langkah pembelajaran program linier dengan cara melatih siswa untuk mengerjakan soal-soal pengembangan dan soal cerita tentang program linier. Ketiga, informasi tentang kesulitan belajar dijadikan sebagai masukan untuk melakukan proses pembelajaran secara otentik tentang kesulitan tiap siswa dalam menyelesaikan soal cerita tentang program linier. Keempat, refleksi dilakukan sebagai langkah akhir untuk menyamakan persepsi tentang kesulitan 
belajar dan menumbuhkan rasa ingin tahu untuk mengerjakan soal-soal program linier. Jenis bimbingan bisa dilakukan dengan memberikan penguatan kembali dalam mempelajari materi prasyarat sebelum mempelajari program linier, kemampuan awal yang harus dimiliki siswa diantaranya menguasai materi sistem persamaan linier, sistem pertidaksamaan linier serta mahir dalam menghitung.

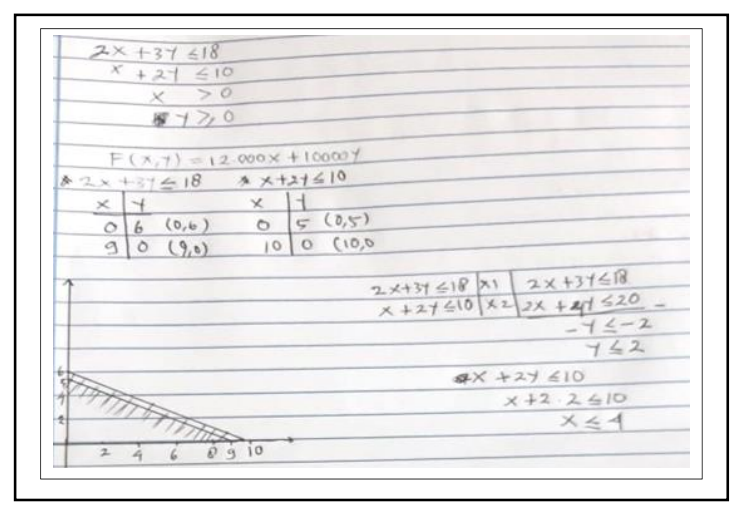

Gambar 5 Data 5 Hasil Uji Kompetensi Program Linier

Gambar 5 menjelaskan tentang kemajuan yang dialami siswa, hal ini dibuktikan dengan siswa sudah mampu membuat titik koordinat dari sistem persamaan linier, walaupaun masih ada kesalahan berupa menuliskan titik koordinat berupa tanda kurung. Perkembangan siswa seperti pada data 5 menunjukkan bahwa jika diberikan bimbingan secara bertahap maka siswa selalu mengalami kemajuan dan sesuai dengan harapan yakni menyelesaikan soal dengan langkah-langkah program linier yang tepat.

\section{B. Efektivitas Penilaian Otentik dan Problem- based learning dalam Mengatasi Kesulitan Belajar \\ Penilaian otentik dapat memberikan} deskripsi secara detail mengenai tingkat kesulitan belajar siswa. Karakteristik siswa dengan tingkat kesulitan yang berbeda serta pemahaman yang berbeda memerlukan bimbingan tiap individu untuk memperoleh masukan terhadap kesulitan yang dihadapi. Berdasarkan penelitian yang telah dilakukan penelitian otentik mampu mengukur dan memaparkan tingkat pemahaman siswa berdasarkan hasil uji kompetensi yang telah dilakukan. Penilaian otentik tiap siswa mampu memberikan masukan untuk perbaikan dan evaluasi terhadap proses pembelajaran yang dilakukan.

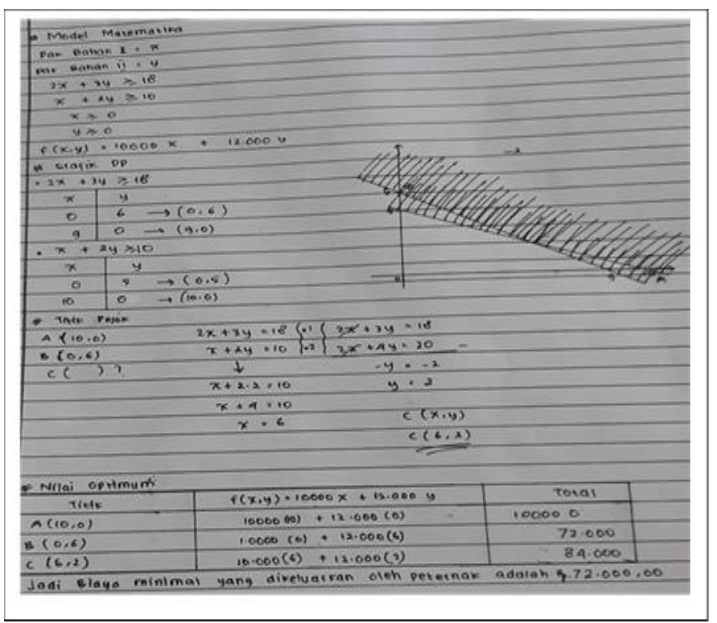

\section{Gambar 6 Data 6 Hasil Uji Kompetensi Program Linier}

Gambar 6 menunjukkan bahwa penilaian otentik yang dilakukan oleh guru untuk mengetahui kemampuan tiap siswa tentunya selalu berakibat positif, hal ini ditunjukkan dengan perkembangan siswa dari yang mengalami kesulitan sampai menunjukkan perkembangan dengan menuliskan langkah-langkah terstruktur dan benar dalam mengerjakan soal program linier. Proses siswa mulai dari menterjemahkan soal sampai menuliskan model matematika, menentukan titik koordinat dari sistem persamaan linier, membuat grafik, dan menentukan titik potong sudah mengalami perkembangan yang signifikan. Siswa dapat berkembang karena usaha dan konsentrasi yang digunakan pembelajaran, hal ini ditunjukkan pada data 6 dengan tingkat hasil proses pembelajaran yang terus berkembang.

\section{SIMPULAN}

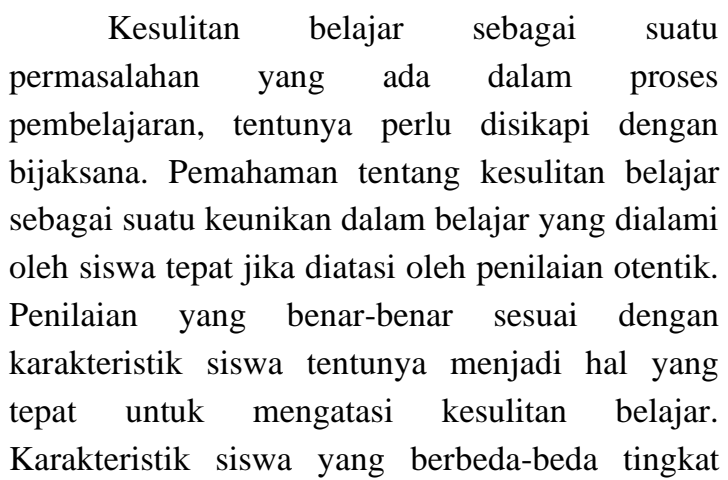


kesulitannya maka perlu diatasi dengan penyelesaian yang berbeda.

Penelitian ini membuktikan bahwa kesulitan belajar pada materi program linier dapat diketahui melalui faktor otentik berupa tingkat pemahaman siswa terkait soal uji kompetensi yang telah dilakukan. Melalui analisis faktor otentik maka, pembelajaran pada materi program linier dapat mengenali karakterik pemahaman siswa terhadap materi yang dipelajarinya.

\section{DAFTAR PUSTAKA}

Alawiyah, H., Muldayanti, N.D., Setiadi, A.E. 2016. Analisis Kesulitan Belajar Siswa dalam Memahami Materi Invertebrata di Kelas X MAN 2 Pontianak. Jurnal Biologi Education, 3(2): 9-20.

Astriyandi, A., Chotimah, U., Faisal, E.E. 2016. Kemampuan Guru Menerapkan Penilaian Autentik dalam Pembelajaran PPKn (Studi Kasus di SMA Negeri 1 Indralaya). Jurnal Bhinneka Tunggal Ika, 3(2): 187-198.

Badjeber, R., Mailili, W.H. 2019. Profil Pengetahuan Konseptual Matematis Siswa SMP Ditinjau dari Gaya Kognitif. Anargya: Jurnal Ilmiah Pendidikan Matematika, 2(1), 6-12.

Cahyono, H. 2019. Faktor-Faktor Kesulitan Belajar Siswa MIN Janti. JDPP, Jurnal Dimensi Pendidikan dan Pembelajaran, 7(1): 1-4.

Hajaroh, S., Adawiyah, R. 2018. Kesulitan Guru dalam Mengimplementasikan Penilaian Autentik. El-Midad, Jurnal Jurusan PGMI, 10(2), 131-152.

Kusuma, J.W., Hamidah. 2019. Pengaruh Model Pembelajaran Arias dan Cooperative Script Terhadap Minat dan Hasil Belajar Matematika. Anargya: Jurnal Pendidikan Matematika, 2(1): 64-69.

Lismayanti, D. 2017. Analisis Kebutuhan Terhadap Pengembangan Instrumen Penilaian Otentik di Madrasah Aliyah Negeri 2 Kota Bengkulu. Manhaj, 1(1): $1-14$.

Nurafni, A., Pujiastuti, H. 2019. Analisis Kemampuan Koneksi Matematis Ditinjau dari Self Confidence Siswa: Studi Kasus di SMKN 4 Pandeglang. Anargya: Jurnal Ilmiah Pendidikan Matematika, 2(1): 2733.

Rahmah. 2013. Analisis Faktor Kesulitan Belajar Siswa dalam Meningkatkan Hasil Belajar pada Mata Pelajaran Sosiologi Kelas XII IPS di MA. Syarif Hidayatullah Pontianak. Jurnal Pendidikan Sosiologi dan Humaniora, 4(1): 87-101.

Saodah, O. 2017. Penilaian Otentik Mata Pelajaran Ilmu Pengetahuan Alam di Sekolah Menengah Pertama Labschool Kebayoran Baru. JPPP, Jurnal Penelitian dan Penilaian Pendidikan, 2(1): 18-32. 